\title{
Effect of premilking teat sanitation on milk composition, somatic cell count and test day milk yield in Holstein cows
}

\author{
Edit Mikóné Jónás ${ }^{1}$, Savas Atasever ${ }^{2 *}$ and Erika Havranek ${ }^{1}$ \\ Institute of Animal Science and Wildlife Management, Faculty of Agriculture, \\ University of Szeged, Hódmezóvásárhely, Hungary.
}

Received: 29-11-2016

Accepted: 09-03-2017

DOI: 10.18805/ijar.v0iOF.8480

\begin{abstract}
The objective of the present study was to determine the efficacy of premilking teat sanitation applications on milk composition, somatic cell count (SCC) and test day milk yield (TDMY) in Holstein cows. The research was conducted in two private farms located in Hódmezõvásárhely, South- Hungary. In the first trial, only water and drying application (WD) was practiced to 791 cows and in the second trial, disinfectant solution and drying application (DD) was performed to 1418 cows. Fat (F), protein (P) and lactose (L) were tested as the milk parameters and SCC and TDMY records were also evaluated. To investigate the effects of non-genetic factors on the parameters, four parity and three days in milk groups were designed. L, SCC and TDMY were affected by parity in both applications, and $\mathrm{P}$ affected by DD $(\mathrm{P}<0.01)$. All traits were affected by DIM in both applications ( $\mathrm{P}<0.05$ or $\mathrm{P}<0.01$ ). While positive correlations were estimated between $\mathrm{F}$ and $\mathrm{P} ; \mathrm{F}$ and $\mathrm{SCC} ; \mathrm{P}$ and SCC; L and TDMY; the negative correlations were determined between F and L; F and TDMY; P and L; P and TDMY; L and SCC; SCC and TDMY. The means of F, P and SCC were higher in DD, but L and TDMY were higher in WD $(\mathrm{P}<0.05)$. The study revealed that cleaning the udder using plenty of water and drying the teats with clean clothes are suggested to dairy owners as a preferential premilking application to obtain high quality milk.
\end{abstract}

Key words: Cow, Milk content, Milk production, Premilking management, Somatic cell count, Udder hygiene.

\section{INTRODUCTION}

The contents of bovine milk has a great importance for dairy sector and obtaining more milk with high quality is a principal target of dairy cattle farms in many countries. To assess milk quality, percentages of basic milk components such as fat $(\mathrm{F})$, protein $(\mathrm{P})$ and lactose (L) are commonly used (Yoon et al., 2004; Yang et al., 2013). Many researchers have informed the correlations of these parameters with milk production levels (Yoon et al., 2004; Stadnik and Atasever, 2015; Mikone Jonas et al., 2016). According to cattle breeds, routinely observing the acceptable percentages of the contents are advised to dairy owners. In spite of bacterial test is the most effective method to determine raw milk quality, somatic cell count (SCC), which has been assumed to be a reliable indirect marker, is widely used to predict quality of milk and also an intramammary infection of udder gland (Mammadova and Keskin, 2015; Jadhav et al., 2016). Somatic cells are mainly milk-secreting epithelial cells that have been shed from the lining of the udder gland and leukocytes that have passed into mammary gland to compete with infection (Sharma et al., 2011). Reports have emphasized that good hygiene practices before the milking times are powerful processes to remove microorganisms from the teat-skin area and to obtain raw milk with low SCC
(Gibson et al., 2008; Sandrucci et al., 2014). In normal, microorganisms enter raw milk either from the environment of cow's or from the udder (Miseikiene et al., 2015). That's why, proper milking hygiene practice is a key subject for ensuring high quality raw milk. Gibson et al. (2008) point out that different teat cleaning techniques show a variation by their effectiveness to remove teat microbial amounts. Some field studies have also been conducted to reveal the most effective practice for boosting hygienic quality of bovine milk (Pavicic et al., 2008; Islam et al., 2009). Kamal and Bayoumi (2015) emphasized that premilking teat dipping is essential to decrease the microorganism level, postmilking applications have mainly been performed in highly infected cattle herds. Kumar et al. (2012) informed that premilking disinfection greatly reduces environmental bacteria amount and prevent new clinical mastitis cases in the herds. In the view of mentioned studies, there is still an argument on which way is the most effective to achieve quality and high quantity raw milk from cows. Investigating the proper premilking management application will help for solving an important concern of dairy farmers.

The aim of this investigation was to reveal the effects of two different premilking teat sanitation applications

\footnotetext{
*Correspondence: satasev@omu.edu.tr, ${ }^{1}$ Institute of Animal Sci. and Wildlife Management, Faculty of Agriculture, University of Szeged, Hódmezóvásárhely, Hungary.

${ }^{2}$ Ondokuz Mayis University, Faculty of Agriculture, Dep. Animal Husbandry, 55139, Samsun, Turkey.
} 
on milk composition, SCC and milk production in Holstein cows.

\section{MATERIALS AND METHODS}

Two trials were carried out in two private dairy farms in Hódmezõvásárhely, South- Hungary. The first farm had approx. 950 milking cows, and 791 healthy ones of those were examined. Before the milkings, only water was used and then dried with papers (Trial 1: WD) The second farm had approx. 1450 cows, and 1418 clinically healthy cows were investigated. For premilking application, a disinfectant solution (iodophore $0.5 \%$ ) was used to clean teats and then dried with papers (Trial 2: DD) in the second farm. Both farms were situated in the same region and all the cows were kept in similar feeding and management conditions during the investigation period (about $1 \mathrm{mo}$ ). The cows were milked three times a day and the daily diets were formulated with a ration preparing program. The parameters were recorded by dairy management software programs. The milk parameters (F, P, L and SCC tests were analyzed by a spectrometer and a milk analyzer. The SCC values were transformed to logarithmic scale $(\log 10)$ to provide homogeneity of variance for statistical study.

To determine effects of environmental factors on all parameters, four parity (cows with parity $\geq 4$ were combined into 4th group) and three days in milk (DIM) groups $(1=\leq 100 d, 2=101-200 d$ and $3=\geq 201 d)$ were designed. The data were tested by analysis of variance (OneWay ANOVA) and means were compared by Duncan's multiple comparison test. The linear model was as follows:

$Y i j=\mu+\alpha i+e i j$

where: Yijk: is dependable variable (parameters),

$\mu$ : population mean,

$\alpha i$ : effect of environmental factors (parity or days in milk) and

eij: random residual.

The difference in the means of the parameters by DD and WD applications was investigated by Independent Sample t-test. Relationships among the parameters were estimated by Pearson's phenotypic correlation coefficients and all statistical works were performed using SPSS 17.0 for Windows.

\section{RESULTS AND DISCUSSION}

Effects of parity and DIM on some milk components (F, P and L), $\operatorname{logSCC}$ and TDMY for two different trials (WD and DD) are shown in Table 1. As seen, no effect of parity on $\mathrm{F}$ was determined for the both practices. However, parity significantly $(\mathrm{P}<0.01)$ affected $\mathrm{P}$ in Trial 2 . Yoon et al. (2004) reported that milk F and $\mathrm{P}$ percentages tended to be decreased until the fifth parity. Yang et al. (2013) emphasized that $\mathrm{F}$ and $\mathrm{P}$ contents were reduced rapidly in the fourth lactation in Chinese Holstein cows. In this investigation, an alternative means were obtained for $\mathrm{P}$ according to parity groups. At this point, findings determined here were found to be different from the mentioned study results.

As a general concept that $\mathrm{L}$ is a main reflector of milk volume (Gurmessa and Melaku, 2012) and its level tended to decrease with advanced age. For L concentrate, similar results were obtained by parity factor in both trials (Table 1). Actually, highest mean was calculated from the cows with first parity and a gradual reduction was observed in the later parity groups. These findings were found to be in confirmity with the report of Yang et al. (2013) but disagreed with the results of Gurmessa and Melaku (2012).

As expected, the lowest logSCC mean was obtained from primiparous cows and the highest one was calculated from those with advanced parities for both trials (Table 1). Mikone Jonas et al. (2016) also reached similar results in their studies. Increased milk production and enhanced udder gland with higher parities could be caused to an increment in SCC of raw milk. Also, abrasions in udder gland could be assumed as one of the main reasons of elevated SCC with higher parity or age. Sharma et al. (2011) indicated that the elevation of SCC is mainly due to an increased prevalence of infection in older cows and is not due to any large increase due to age per se. Similar findings in TDMY across parities were observed for two different practices As seen that, DIM significantly $(\mathrm{P}<0.05$ or $\mathrm{P}<0.01)$ affected all parameters in both trials (Table 1). While the highest $\mathrm{F}$ means were recorded from the last DIM group (DIM 3), the lowest F means were obtained from the second and first DIM groups for WD and DD, respectively. In a normal condition, a decline in F percentage with an elevated milk yield may be assumed as an expected result. Correlation coefficients among P, L, SCC and TDMY were estimated for two trials. These findings agreed with the results of Mikone Jonas et al. (2016). The results clearly revealed that $\mathrm{F}$ and $\mathrm{P}$ were lower, but TDMY higher in cows at lower than $100 \mathrm{~d}$ of lactation $(\leq 100 d)$. This result could be due to the fact that milk yield achieves peak point at the first stage of the lactation period in milking cows. At this point, it can be suggested to dairy herd owners that cows at the middle or late lactation stages should conscientiously managed to ensure more milk quality and quantity.

In this investigation, positive associations were estimated between $\mathrm{F}$ and $\mathrm{P}$ or $\log \mathrm{SCC}$; but negative correlations were calculated between $\mathrm{F}$ and L or TDMY (Table 2). These findings were found similar to the results of Yoon et al. (2004). Because of SCC has been used a reliable reflector to detect milk quality or any abnormality (Sharma et al., 2011), F and P values may also be useful to decide milk quality degree. Also, $\mathrm{P}$ was found to be negatively correlated with L and TDMY in the present study. To obtain more milk, monitoring these components may be advised to herd owners. A negative and highly significant 
Volume 52 Issue 7 (July 2018)

Table 1: Effects of parity and days in milk on milk composition, somatic cell count and test day milk yield in different premilking trials

\begin{tabular}{lllllll}
\hline Factor & $\mathbf{n}$ & Fat $(\%)$ & Protein $(\%)$ & Lactose (\%) & LogSCC & TDMY (kg) \\
\hline \multicolumn{2}{l}{ Trial 1 } & & & & & \\
Parity & & & & & & \\
\hline 1 & 244 & 3.66 & 3.43 & $4.96 \mathrm{C}$ & $4.93 \mathrm{~A}$ & $32.059 \mathrm{~A}$ \\
2 & 256 & 3.70 & 3.39 & $4.90 \mathrm{~B}$ & $5.00 \mathrm{AB}$ & $36.865 \mathrm{~B}$ \\
3 & 138 & 3.73 & 3.36 & $4.88 \mathrm{~B}$ & $5.06 \mathrm{~B}$ & $37.749 \mathrm{~B}$ \\
4 & 153 & 3.74 & 3.38 & $4.80 \mathrm{~A}$ & $5.19 \mathrm{C}$ & $36.470 \mathrm{~B}$ \\
Total & 791 & $3.70 \pm 0.71$ & $3.40 \pm 0.34$ & $4.89 \pm 0.23$ & $5.03 \pm 0.46$ & $35.460 \pm 10.477$ \\
\hline
\end{tabular}

Trial 2

Parity

\begin{tabular}{lllllll}
\hline 1 & 600 & 3.85 & $3.50 \mathrm{~A}$ & $4.95 \mathrm{C}$ & $5.00 \mathrm{~A}$ & $33.31 \mathrm{~A}$ \\
2 & 412 & 3.88 & $3.60 \mathrm{~B}$ & $4.85 \mathrm{~B}$ & $5.23 \mathrm{~B}$ & $5.39 \mathrm{C}$ \\
3 & 250 & 3.96 & $3.55 \mathrm{AB}$ & $4.81 \mathrm{~A}$ & $37.20 \mathrm{~B}$ & $3.40 \mathrm{C}$ \\
4 & 156 & 3.91 & $3.54 \mathrm{~A}$ & $4.79 \mathrm{~A}$ & $35.82 \mathrm{~B}$ & $5.18 \pm 0.60$ \\
Total & 1418 & $3.88 \pm 0.85$ & $3.54 \pm 0.37$ & $4.88 \pm 0.18$ & $35.07 \pm 11.68$ \\
\hline
\end{tabular}

\begin{tabular}{|c|c|c|c|c|c|c|}
\hline \multicolumn{7}{|c|}{ Trial 1} \\
\hline 1 & 239 & $3.62 \mathrm{~B}$ & $3.16 \mathrm{~A}$ & $4.99 \mathrm{~B}$ & $4.98 \mathrm{~A}$ & $44.16 \mathrm{C}$ \\
\hline 2 & 248 & $3.48 \mathrm{~A}$ & $3.35 \mathrm{~B}$ & $4.97 \mathrm{~B}$ & $4.98 \mathrm{~A}$ & $37.16 \mathrm{~B}$ \\
\hline 3 & 304 & $3.95 \mathrm{C}$ & $3.62 \mathrm{C}$ & $4.76 \mathrm{~A}$ & $5.10 \mathrm{~B}$ & $27.22 \mathrm{~A}$ \\
\hline Total & 791 & $3.70 \pm 0.71$ & $3.40 \pm 0.34$ & $4.89 \pm 0.23$ & $5.03 \pm 0.46$ & $35.460 \pm 10.477$ \\
\hline \multicolumn{7}{|c|}{ Trial 2} \\
\hline 1 & 419 & $3.60 \mathrm{~A}$ & $3.27 \mathrm{~A}$ & $4.92 \mathrm{~B}$ & $5.14 \mathrm{a}$ & $40.85 \mathrm{C}$ \\
\hline 2 & 468 & $3.81 \mathrm{~B}$ & $3.54 \mathrm{~B}$ & $4.91 \mathrm{~B}$ & $5.15 \mathrm{a}$ & $37.27 \mathrm{~B}$ \\
\hline 3 & 531 & $4.17 \mathrm{C}$ & $3.76 \mathrm{C}$ & $4.82 \mathrm{~A}$ & $5.24 b$ & $28.57 \mathrm{~A}$ \\
\hline Total & 1418 & $3.88 \pm 0.85$ & $3.54 \pm 0.37$ & $4.88 \pm 0.18$ & $5.18 \pm 0.60$ & $35.07 \pm 11.68$ \\
\hline
\end{tabular}

Different superscript letters in the same column indicate statistically significant differences (a, b: $\mathrm{P}<0.05 ; \mathrm{A}, \mathrm{B}: \mathrm{P}<0.01$ )

TDMY: Test day milk yield; logSCC: logarithmic somatic cell count; DIM: days in milk: $1=\leq 100 d, 2=101-200 d$ and $3=\geq 201 d$

Trial 1: wash + drying (WD) and Trial 2: disinfectant + drying (DD) as premilking application

Table 2: Phenotypic correlation coefficients between milk composition, somatic cell count and test day milk yield in two different trials

\begin{tabular}{|c|c|c|c|c|}
\hline Parameter & Protein & Lactose & $\operatorname{LogSCC}$ & DMY \\
\hline Fat & $0.604 * * / 0.517 * *$ & $-0.300 * * /-0.255 * *$ & $0.102 * * / 0.107 * *$ & $-0.425 * * /-0.393$ \\
\hline Protein & & $-0.326 * * /-0.283 * *$ & $0.171^{* *} / 0.175^{* *}$ & $-0.454 * * /-0.631 * *$ \\
\hline Lactose & & & $-0.437 * * /-0.308 * *$ & $0.402 * * / 0.454 * *$ \\
\hline $\operatorname{LogSCC}$ & & & & $-0.290 * * /-0.205 * *$ \\
\hline
\end{tabular}

**: $\mathrm{P}<0.01$

(The first and second coefficients are belonging to WD and DD, respectively)

correlation coefficient was also determined between logSCC and TDMY and this association was higher in WD application. In this context, routine control of SCC may be seen as a crucial approach to boost quality milk production in dairy herds where any premilking hygiene practices are applied..

A comparative assessment of the investigated parameters by two different trials is presented in Fig 1. According to $t$-test results, premilking management practices affected the parameters $(\mathrm{P}<0.05$ or $\mathrm{P}<0.01)$. As expected, $\mathrm{F}$ and $\mathrm{P}$ means had similar trend; and both values were lower in milk samples collected from cows those exposed to WD. When the udder gland is evaluated as a bucket, cleaning the udder with plenty of water and the potential effect of water to shake the milk before the milking process may be explained as the possible reason of this case. However, relatively higher $(\mathrm{P}<0.05)$ average was obtained from the WD application for $\mathrm{L}$ means. Some important findings were recorded for $\operatorname{logSCC}$ and TDMY means. The WD application significantly reduced $\operatorname{logSCC}$ $(\mathrm{P}<0.05)$ and raised TDMY $(\mathrm{P}<0.01)$. These findings can be correlated to previous results. In other words, WD application was found as $0.39 \mathrm{~kg}$ more favorable per milking cow when 


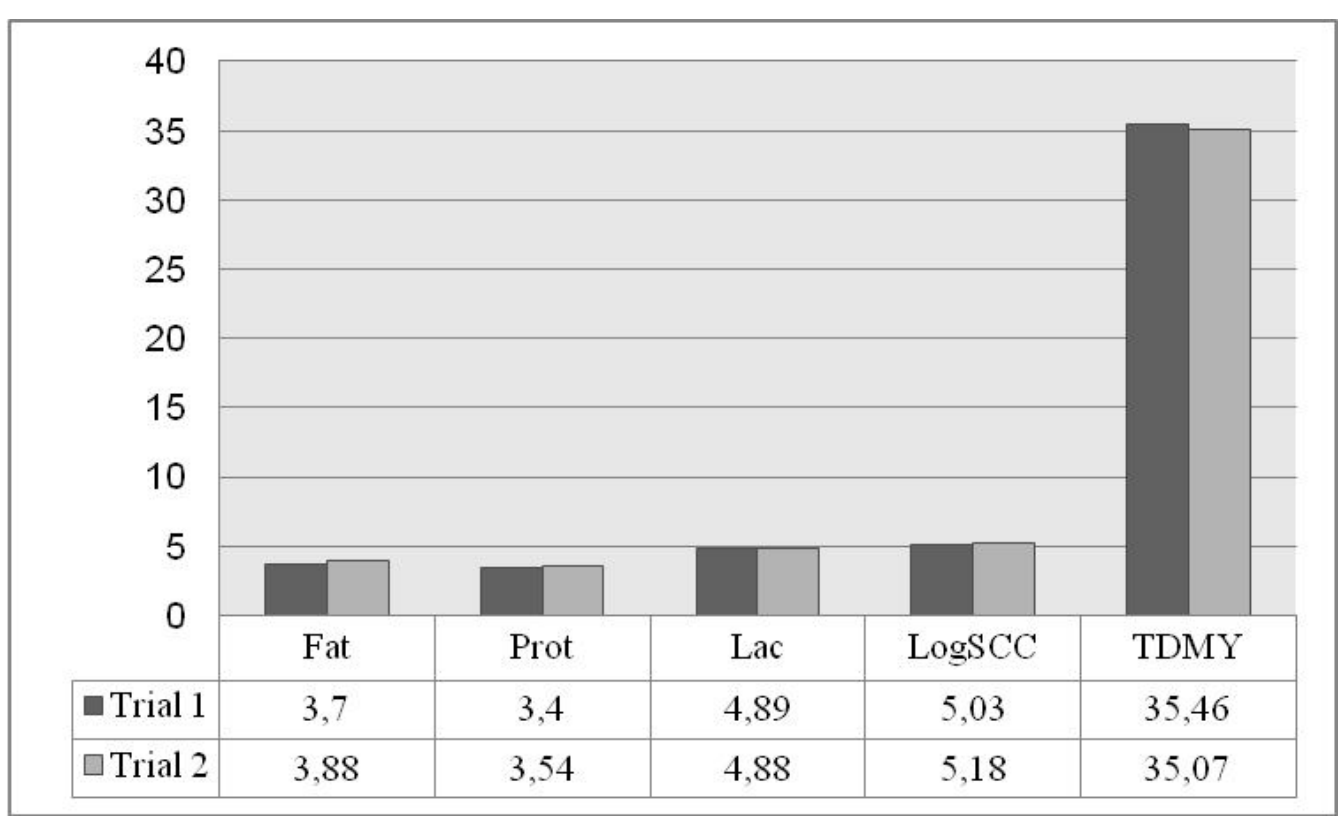

Fig 1: Estimates of milk composition, somatic cell count and test day milk yield under different premilking sanitation applications

(TDMY: test day milk yield; logSCC: logarithmic somatic cell count; Trial 1 reflects: wash + drying and Trial 2: disinfectant + drying )

compared to DD application. This finding may be explained by milk secretion reflex of the cow's udder because of exposing to plenty of water. Moreover, the untransformed SCC mean of $\mathrm{WD}(219 \mathrm{x} 1000$ cells $/ \mathrm{ml})$ was approximately half of the estimate obtained after DD application ( $443 \times 1000$ cells $/ \mathrm{ml})$. The present findings could be attributed to the exposure of only teats and partial surroundings of the teats in DD application, but in addition to teats, udder and breast skin, and some parts of the flanks are cleaned with water in premilking application with WD.
Finally, it is concluded that sole DD application is not a penetrating disinfection tool to achieve raw milk sanitation in dairy herds. In the view of the revealed findings of the present investigation, cleaning the udder using plenty of water and drying the teats with clean clothes may be suggested to dairy owners as the preferential premilking application to prevent new intramammary infections and to obtain more milk production.

\section{REFERENCES}

Atasever, S. and Stadnik, L (2015). Factors affecting daily milk yield, fat and protein percentage, and somatic cell count in primiparous Holstein cows. Indian J. Anim. Res., 49: 313-316.

Gibson, H., Sinclair, L.A., Brizuela, C.M., Worton, H.L. and Protheroe, R.G. (2008). Effectiveness of selected premilking teat-cleaning regimes in reducing teat microbial load on commercial dairy farms. Lett. Appl. Microbiol., 46: 295-300.

Gurmessa, J. and Melaku, A. (2012). Effect of lactation stage, pregnancy, parity and age on yield and major components of raw milk in bred cross Holstein Fresian cows. World J. Dairy Food Sci., 7: 146-149.

Islam, M.A., Islam, M.N., Khan, M.A.S., Rashid, M.H. and Obaidullah, S.M. (2009). Effect of different hygienic condition during milking on bacterial count of cows' milk. Bang. J. Anim. Sci., 38: 108-114.

Jadhav, P.V., Tarate, S.B., Bhuvana, M., Das, D.N. and Shome, B.R. (2016). Somatic cell count as a monitoring system for hygienic milk production in India: A review. Asian J. Dairy \& Food Res., 35: 270-277.

Kamal, R.M. and Bayoumi, M.A. (2015). Efficacy of premilking and postmilking teat dipping as a control of subclinical mastitis in Egyptian dairy cattle. Int. Food Res. J., 22: 1037-1042.

Kumar, A.V., Rao, L.V., Kumar, M.K., Srinu, B. and Rao, T.M. (2012). Efficacy of udder disinfectants on reduction of bacterial load and certain pathogens of public health significance. J. Microbiol. Biotech. Res., 2: 147-151.

Mammadova, N.M. and Keskin, I. (2015). Application of neural network and adaptive neuro-fuzzy inference system to predict subclinical mastitis in dairy cattle. Indian J. Anim. Res., 49: 671-679.

Mikone Jonas, E., Atasever, S., Graff, M. and Erdem, H. (2016). Non-genetic factors affecting milk yield, composition and somatic cell count in Hungarian Holstein cows. Kafkas Univ. Vet. Fak. Derg., 22: 361-366. 
Miseikiene, R., Rudejeviene, J. and Gerulis, G. (2015). Effect of pre-milking antiseptic treatment on the bacterial contamination of cow teats' skin. Bulgarian J. Vet. Med., 18: 159-166.

Pavicic, Z., Cergolj, M., Balenovic, T., Ekert-Kabalin, A. and Valpotic, H. (2008). Influence of udder sanitation on hygienic quality of cow milk. Vet. Arhiv., 78: 105-112.

Sandrucci, A., Bavai L., Zucali, M. and Tanburini, A. (2014). Management factors and cow traits influencing milk somatic cell counts and teat hyperkeratosis during different seasons. R. Bras. Zootec., 43: 505-511.

Sharma, N., Singh, N.K. and Bhadwal, M.S. (2011). Relationship of somatic cell count and mastitis: an overview. Asian-Aust. J. Anim. Sci., 24: 429-438.

Stadnik, L. and Atasever, S. (2015). Influence of some environmental factors on body condition score and somatic cell count in Czech Holstein cows. Indian J. Anim. Res., 49: 774-777.

Yang, L., Yang, Q., Yi, M., Pang, Z.H. and Xiong, B.H. (2013). Effects of seasonal change and parity on raw milk composition and related indices in Chinese Holstein cows in northern China. J. Dairy Sci., 96: 6863-6869.

Yoon, J.T., Lee, J.H., Kim, C.K., Chung, Y.C. and Kim, C.H. (2004). Effects of milk production, season, parity and lactation period on variations of milk urea nitrogen concentration and milk components of Holstein dairy cows. Asian Australas. J. Anim. Sci., 17: $479-484$ 